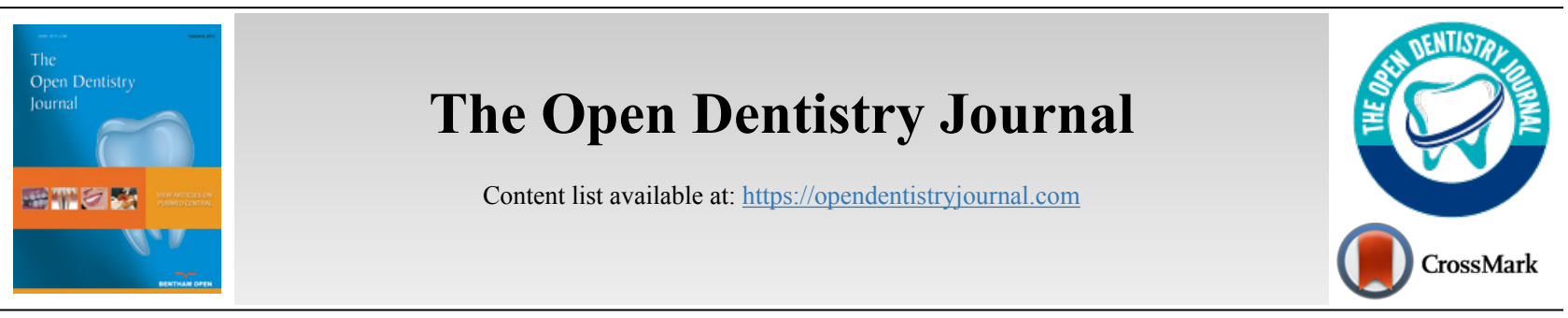

RESEARCH ARTICLE

\title{
Factors Behind Leaving the Job and Rejoining it by the Japanese Dental Hygienist
}

Yoshiaki Nomura ${ }^{1, *}$, Ayako Okada ${ }^{2}$, Yuko Yamamoto ${ }^{3}$, Erika Kakuta ${ }^{4}$, Hiroshi Tomonari ${ }^{5}$, Noriyasu Hosoya ${ }^{3}$, Nobuhiro Hanada $^{1}$, Naomi Yoshida ${ }^{6,7}$ and Noriko Takei ${ }^{6}$

${ }^{1}$ Department of Translational Research, Tsurumi University School of Dental Medicine, Yokohama, Japan

${ }^{2}$ Department of Operative Dentistry, Tsurumi University School of Dental Medicine, Yokohama, Japan

${ }^{3}$ Department of Endodontics, Tsurumi University School of Dental Medicine, Yokohama, Japan

${ }^{4}$ Department of Oral Microbiology, Tsurumi University School of Dental Medicine, Yokohama, Japan

${ }^{5}$ Department of Orthodontics, Tsurumi University School of Dental Medicine, Yokohama, Japan

'Japanese Dental Hygienists' Association, Tokyo, Japan

${ }^{7}$ Department of Oral Health Care Education, Graduate School of Medical and Dental Sciences, Tokyo Medical and Dental University, Tokyo, Japan

\begin{abstract}
:
Aim:

To investigate the factors that countermeasure the re-entry of Japanese dental hygienist.

Background:

The number of currently working dental hygienists is not sufficient. About $40 \%$ licensed dental hygienist are leaving their professional jobs. Reentry of the dental hygienist who have left is expected to compensate the unbalance of demand and supply.

Objective:

The purpose of this study was to identify the obstacles faced during re-entry by the dental hygienists and propose the countermeasures for supporting re-entry.

Methods:

The Japan Dental Hygienist Association conducts survey of the Employment Status of Japanese dental hygienist every 5 years since 1981.Questionnaires were distributed for all members of the Japan Dental Hygienists Association. Among the 94 items, following eight specific items were used for analysis: 1 . The reason of leaving the job. 2. For how long have you left the job? 3. Willingness to reenter. 4. How do you find your work for re-entry? 5. Is there any obstacle in the reentry? 6 . What is the obstacle faced by you during reentry? 7 . Do you need lecture course for reentry? 8 . What kind of lecture course contents do you want to attend?

Results:

Questioners were distributed among the 16,113 members of Appeases Dental hygienist Association, and out of which 8,780 responded (collection rate:54.5\%). By log-linear analysis, the reason behind leaving the job were dissatisfaction with work content and marriage significant in age groups $\leq 29$ and 30-39. Child birth / child rearing was significant in age groups $\leq 29,30-39$ and 40-49. Payment was significant in 30-39 and 40-49. Child birth / rearing and working hours had the most important impacts on leaving the job and were among the obstacle for reentry. In this study, a number of dental hygienist who leave the job due to child birth / rearing was highest.

\section{Conclusion:}

There was a limitation for sampling frame of this study. Workplace improvement including flexible working time may be the most important factors for the reentry of the dental hygienist who had left their jobs previously.Social support system is indispensable to improve women's working environment.
\end{abstract}

Keywords: Dental Hygienist, Leaving job, Reentry, Working environment, Log-linear analysis, Working hours.

\begin{tabular}{l|l|l|r} 
Article History & Received: January 22, 2020 & Revised: April 22, 2020 & Accepted: April 29, 2020
\end{tabular}




\section{INTRODUCTION}

Japan has problems such as birthrate decline, population aging due to which shrinkage of the working population continues to be unabated. The population of Japan in 2018 consisted of $28.0 \%$ elderly population (over 65 years old) and $59.7 \%$

production age population (15-64 years old) [1]. In order to support this aging society, the Japanese government is advancing counter measures for declining birthrate and reforming work. In work reforms, women's reentry to work and reemployment of retired workers due to age are the main stream. For the improvement of women's working environment, child - rearing support system has been improved so that women during child - rearing can easily work, but the number of kinder gardens, nursery schools, nursery and day care centers for children and day nursery are not still enough. The number of nursery teachers and childcare workers are also notsufficient. Gender barriers still exist in working environment, especially in wages.

There are approximately 200,000 licensed dental hygienists in Japan, and the currently working dental hygienist were 123,831 [2]. About 40\% licensed dental hygienist are leaving their professional jobs. In Japan's aging society, there is a massive need for oral care of the elderly. According to the demographics of 2017 in Japan, the number of deaths by pneumonia excluding aspiration pneumonia was 96,807 . It was considered the $5^{\text {th }}$ most common cause of Japanese death. The number of deaths by aspiration pneumonia was 35,740 . It was considered the $7^{\text {th }}$ most common cause of death in Japan. Crude death rate of aspiration pneumonia and pneumonia has been increaing [3]. Many studies have confirmed the effect of professional oral care for the prevention of pneumonia including aspiration [4 - 7] or influenza [8].

Dental hygienists play a pivotal role in preventing aspiration pneumonia, and despite their expected role, the number of dental hygienists is not sufficient. In the current situation of one dental hygienist to approximately 1000 people, it is difficult to meet the requirement.

In the Japanese's system of dental service, dental clinics are the main constituent and most of them are private dental clinics. The number of dental clinics was 68,940 in 2017 [9]. Of the 123,831 working dental hygienists, 112,211 (90.6\%) were working in the clinics [2]. The average number of dental hygienists per clinic is 1.6 , which includes part-time workers. Working dental hygienists are not sufficient. As welfare programs of private dental clinics are not substantial like civil servants and large corporate workers, dental hygienists are unable to obtain a sufficient vacation due to marriage, childbirth, child rearing, and are now leaving. As mentioned above, child - rearing support system in Japan is still not sufficient. Therefore, it is difficult to reinstate in short periods.

In this situation, the re-entry of dental hygienist who had left their jobs previously is expected to compensate the

\footnotetext{
* Address correspondence to this author at the Department of Translational Research, Tsurumi University School of Dental Medicine, 2-1-3 Tsurumi, Tsurumi-ku, Yokohama 230-8501, Japan; Tel: (+81) 45-580-8462; Fax: (+81) 45-573-2473; E-mail: nomura-y@tsurumi-u.ac.jp
}

unbalance of demand and supply. However, limited information is available for the leaving dental hygienist, because of its information by their local area [10.11] and small samples [12]. From this point of view, the Japanese Dental Hygienist Association has conducted a survey on working conditions of hygienists on a nationwide scale every five years, including survey items of leaving dental hygienists. However, the results of the survey had been reported by descriptive analysis. Causal and statistical inference had not been conducted. The purpose of this study was to identify the obstacles faced by dental hygienists to re-enter their profession and propose the countermeasures for supporting re-entryby statistical modeling.

\section{METHODS}

\subsection{Survey Method}

The Japan Dental Hygienists Association has been conducting survey of the Employment Status of Japanese dental hygienist every 5 years since 1981 . Questionnaires were distributed to all members of the Japan Dental Hygienists Association on September $30^{\text {th }}, 2014$ by postage painted mail including a stamped addressed envelope for recovery. The survey execution date was set as October $31^{\text {st }}, 2014$. The questionnaires returned until the November $30^{\text {th }}$ were used for the analysis. One of the limitations of this study was this sampling frame. Study population was limited to the members of the Japan Dental Hygienists Association.

\subsection{Questionnaire}

The questionnaire used in this study consisted of 94 items concerning demographic factors, employment situation, working contents, willingness to work etc.

For the leaving dental hygienists, seven specific items were applied (Additional file):

- The reason of leaving the job. Select one. 1.Dissatisfaction with work content, 2. Payment, 3. Trouble in human relations in the workplace, 4. Family Matters, 5. Marriage, 6. Childbirth /child rearing, 7. Nursing care for elderlies of your family, 8. health status 9. Interests other than dental job, 10. Retirement, 11. Others

- Since how long have you left the job?

- Willingness to reentry. Select one. 1 I want to reenter as soon as possible. 2. I want to reenter if conditions are satisfied. 3 . I do not intend to reenter 4. Univalent.

- How do you find your work for re-entry? Multiple choice.

1.Labor agency 2. Job magazines 3 . Introduction from a friend / acquaintance 4 . Introduction of dental hygienist school you graduated from 5 . Internet 6 . Free employment introduction of dental Association and Dental Hygienist Association, 7. Human resource dispatch companies, 8. Other 
- Is there any obstacle in the reentry?

$$
\text { 1.Yes, } 2 \text { No }
$$

- What is your obstacle for reentry?

1 Salary, 2. Working hours, 3. My skills, 4. No consultation 5. Aging 6. Others

- Do you need a lecture course for reentry?

1.Yes, 2 No

- What kind of lecture course contents do you want to attend?

1.Scaling and route planning, 2.Dental caries prevention and control, 3.Dental health guidance for individuals,4.Dental health guidance for group, 5. Handling of dental materials, chair side assistant, 6.Chair side assistant snap impression, polishing of filling materials, rubber dam etc., 7. Nursing care, 8. Eating / swallowing function training, 9.Muscle function training, 10Counseling techniques, 11. Professional oral care techniques, 12. Other

The questionnaire in Japanese is available from JAPAN DENTAL HYGIENISTS' ASSOCIATION [13].

\subsection{Statistical Analysis}

Descriptive statistics and cross tabulations with age groups were summarized for the questions described above. Chisquare tests were used to find out the statistical significance. In addition, logit model of log-linear analysis was carried out to find out the statistically significant cells. For the contentious variables, after confirmation of their normality, one-way analysis of variance and subsequent Turkey HSD was used for the multiple comparison. Decision analysis was carried out by the Classification And Regression Trees (CART), and the willingness to reentry was used for the objective variable. SPSS Statistics Ver 24.0 (IBM, Tokyo) was used for analysis.

\subsection{Ethics Approval and Consent to Participate}

Informed written consent was obtained from all participants. This study was approved by the Ethics Committee of Tsurumi University School of Dental Medicine (approval number:1633) and conducted in accordance with the Declaration of Helsinki.

\section{RESULTS}

Questioners were distributed among 16,113 members of the Japanese Dental hygienist Association, out of which 8,780 responded (collection rate: $54.5 \%$ ). Table 1 shows the cross tabulation of the specific questionnaire for the dental hygienist who left their jobs against age groups. * indicated the statistically significant cells by log-linear analysis. The reason behind leaving the job were dissatisfaction with work content and marriage in age groups $\leq 29$ and 30-39. Childbirth / child rearing in age groups $\leq 29,30-39$ and 40-49. Salaries in 30-39 and 40-49. Trouble in human relations in the workplace only in $\leq 29$. Age groups less than 49 significantly had a willingness of reentry (as soon as possible and If conditions are satisfied).

For job searching, Friends, Dental Association / Dental Hygienist Association, Human resource Dispatch Company were not statistically significant. age groups $\leq 29$ wished to attend the lecture course for reentry,.

For the contents of lecture course, Scaling, root plaining and chair side assistance were significant for age groups $\leq 29$ to 40-49. For the obstacle of reentry, salary, working hours, skills were important obstacles for all ages except for the age group of $60 \leq$, however, the skill was not statistically significant in age groups 30-39.

\section{Table 1. Cross tabulation of the items investigated in this study against age groups.}

\begin{tabular}{|c|c|c|c|c|c|c|c|}
\hline \multirow[t]{2}{*}{-} & \multirow{2}{*}{$\begin{array}{c}- \\
\leq 29 \\
(n=103)\end{array}$} & \multicolumn{5}{|c|}{ Age group } & \multirow{2}{*}{\begin{tabular}{|c}
- \\
p-value
\end{tabular}} \\
\hline & & $\begin{array}{c}30-39 \\
(n=251)\end{array}$ & $40-49(n=295)$ & $\begin{array}{c}50-59 \\
(n=290)\end{array}$ & $\begin{array}{c}60 \leq \\
(n=251)\end{array}$ & \begin{tabular}{c|} 
Total \\
$(\mathrm{n}=1198)$
\end{tabular} & \\
\hline \multicolumn{3}{|l|}{ The reason of leaving the job. (Select one) } & - & - & - & - & - \\
\hline Dissatisfaction with work content & $5(26.3 \%) *$ & $5(26.3 \%) *$ & $5(26.3 \%)$ & $3(15.80 \%)$ & $1(5.30 \%)$ & 19 & \multirow[t]{11}{*}{$<0.001$} \\
\hline Payment & $3(7.1 \%)$ & $6(14.3 \%) *$ & $18(42.9 \%)^{*}$ & $14(33.30 \%)$ & $1(2.40 \%)$ & 42 & \\
\hline Trouble in human relations in the workplace & $8(28.6 \%)^{*}$ & $3(10.7 \%)$ & $11(39.3 \%)$ & $4(14.30 \%)$ & $2(7.10 \%)$ & 28 & \\
\hline Family Matters & $3(2.4 \%)$ & $10(8.1 \%)$ & $52(41.9 \%)$ & $41(33.10 \%)$ & $18(14.50 \%)$ & 124 & \\
\hline Marriage & $12(25.0 \%) *$ & $21(43.8 \%) *$ & $9(18.8 \%)$ & $4(8.30 \%)$ & $2(4.20 \%)$ & 48 & \\
\hline Childbirth / child rearing & $41(16.7 \%)^{*}$ & $151(61.6 \%)^{*}$ & $49(20.0 \%) *$ & $3(1.20 \%)$ & $1(0.40 \%)$ & 245 & \\
\hline Nursing care for elderlies of your family & $2(4.1 \%)$ & $1(2.0 \%)$ & $5(10.2 \%) *$ & $28(57.10 \%)$ & $13(26.50 \%)$ & 49 & \\
\hline Broke down my health & $4(5.5 \%)$ & $10(13.7 \%)$ & $17(23.3 \%)$ & $25(34.20 \%)$ & $17(23.30 \%)$ & 73 & \\
\hline Interests other than dental job & $10(7.6 \%)$ & $14(10.6 \%)$ & $40(30.3 \%)$ & $51(38.60 \%)$ & $17(12.90 \%)$ & 132 & \\
\hline Retirement & $0(0 \%)$ & $3(1.8 \%)$ & $3(1.8 \%)$ & $21(12.80 \%)$ & $137(83.50 \%) *$ & 164 & \\
\hline Others & $12(5.9 \%)$ & $15(7.4 \%)$ & $70(34.3 \%)$ & $79(38.70 \%)$ & $28(13.70 \%)$ & 204 & \\
\hline \multicolumn{2}{|l|}{ Willingness to reentry. (Select one) } & - & - & - & - & - & - \\
\hline As soon as possible & $14(24.1 \%)^{*}$ & $15(25.9 \%) *$ & $20(34.5 \%)^{*}$ & $7(12.10 \%)$ & $2(3.40 \%)$ & 58 & $<0.001$ \\
\hline If conditions are satisfied & $62(12.2 \%) *$ & $177(34.9 \%)^{*}$ & $148(29.2 \%) *$ & $91(17.9 \%)$ & $29(5.70 \%)$ & 507 & \\
\hline I do not intend to & $9(2.5 \%) *$ & $16(4.4 \%) *$ & $52(14.2 \%)^{*}$ & $119(32.5 \%) *$ & $170(46.40 \%)$ & 366 & \\
\hline Univalent & $16(6.7 \%)$ & $41(17.2 \%)$ & $71(29.8 \%)$ & $70(29.4 \%)$ & $40(16.80 \%)$ & 238 & \\
\hline \multicolumn{4}{|c|}{ How do you find your work for reentry? (Multiple choice) } & - & - & - & - \\
\hline
\end{tabular}




\begin{tabular}{|c|c|c|c|c|c|c|c|}
\hline \multirow{2}{*}{\begin{tabular}{|l|}
- \\
Labor agency by Ministry and Labor welfare \\
\end{tabular}} & \multirow{2}{*}{$\frac{-}{23(5.9 \%)^{*}}$} & \multicolumn{5}{|c|}{ Age group } & \multirow{2}{*}{$\frac{-}{<0.001}$} \\
\hline & & $58(15.0 \%) *$ & $104(26.9 \%)^{*}$ & $105(27.1 \%)^{*}$ & $97(25.10 \%)$ & 387 & \\
\hline Job magazines & $58(8.6 \%)^{*}$ & $142(21.0 \%)^{*}$ & $167(24.7 \%) *$ & $176(26.0 \%)^{*}$ & $134(19.80 \%)$ & 677 & $<0.001$ \\
\hline Friend & $50(9.6 \%)$ & $127(24.4 \%)$ & $132(25.3 \%)$ & $132(25.3 \%)$ & $80(15.40 \%)$ & 521 & 0.785 \\
\hline Dental hygienist school & $76(8.1 \%)^{*}$ & $210(22.4 \%)^{*}$ & $253(27.0 \%) *$ & $241(25.7 \%)^{*}$ & $158(16.80 \%)$ & 938 & $<0.001$ \\
\hline Internet & $73(8.8 \%)^{*}$ & $164(19.7 \%)^{*}$ & $219(26.3 \%)^{*}$ & $218(26.2 \%)^{*}$ & $158(19.00 \%)$ & 832 & $<0.001$ \\
\hline Dental Association / Dental Hygienis & $72(9.8 \%)$ & $176(24.0 \%)$ & $180(24.5 \%)$ & $190(25.9 \%)$ & $116(15.80 \%)$ & 734 & 0.121 \\
\hline Human resource dispatch company & $96(9.4 \%)$ & $239(23.5 \%)$ & $269(26.4 \%)$ & $251(24.6 \%)$ & $164(16.10 \%)$ & 1019 & 0.573 \\
\hline Other & $92(9.2 \%)$ & $240(24.0 \%)$ & $274(27.4 \%)$ & $242(24.2 \%)$ & $152(15.20 \%)$ & 1000 & 0.025 \\
\hline \multicolumn{3}{|l|}{ Is there any obstacle for the reentry? (Yes or No) } & - & - & - & - & - \\
\hline Yes & $84(9.4 \%)$ & $212(23.6 \%)^{*}$ & $240(26.7 \%)^{*}$ & $221(24.6 \%)$ & $141(15.7 \%)$ & 898 & 0.064 \\
\hline \multicolumn{3}{|l|}{ What is your obstacle for reentry? (Multiple choice) } & - & - & - & - & - \\
\hline Salary & $60(8.6 \%)^{*}$ & $144(20.6 \%)^{*}$ & $169(24.1 \%)^{*}$ & $189(27.0 \%)^{*}$ & $138(19.70 \%)$ & 700 & $<0.001$ \\
\hline Working hours & $33(8.1 \%)^{*}$ & $44(10.8 \%)^{*}$ & $91(22.3 \%)^{*}$ & $126(30.9 \%)^{*}$ & $114(27.90 \%)$ & 408 & $<0.001$ \\
\hline My skills & $33(7.4 \%)^{*}$ & $126(28.3 \%)$ & $97(21.7 \%)^{*}$ & $99(22.2 \%)^{*}$ & $91(20.40 \%)$ & 446 & $<0.001$ \\
\hline No consultation & $79(9.2 \%)$ & $202(23.5 \%)$ & $233(27.1 \%)$ & $212(24.6 \%)$ & $135(15.70 \%)$ & 861 & 0.822 \\
\hline Aged & $77(12.9 \%)$ & $202(33.9 \%)$ & $191(32.0 \%)$ & $106(17.8 \%)$ & $20(3.40 \%)^{*}$ & 596 & $<0.001$ \\
\hline Others & $69(9.4 \%)$ & $171(23.4 \%)$ & $195(26.7 \%)$ & $181(24.8 \%)$ & $115(15.70 \%)$ & 731 & 0.995 \\
\hline \multicolumn{6}{|c|}{ What kind of lecture course contents do you want to attend for reentry? } & - & - \\
\hline Scaling and route planning & $19(6.0 \%) *$ & $54(17.1 \%)^{*}$ & $90(28.6 \%)^{*}$ & $93(29.5 \%)$ & $59(18.70 \%)$ & 315 & $<0.001$ \\
\hline Dental caries prevention and control & $32(6.7 \%)^{*}$ & $119(24.9 \%)$ & $142(29.8 \%)$ & $120(25.2 \%)$ & $64(13.40 \%)$ & 477 & 0.001 \\
\hline Individual instruction of dental health & $34(8.1 \%)$ & $107(25.4 \%)$ & $133(31.5 \%)$ & $100(23.7 \%)$ & $48(11.40 \%)$ & 422 & 0.297 \\
\hline Group instruction of dental health & $51(10.3 \%)^{*}$ & $132(26.7 \%)$ & $139(28.1 \%)$ & $120(24.2 \%)^{*}$ & $53(10.70 \%)$ & 495 & 0.079 \\
\hline Handling of dental materials, chair side assistant & $40(8.5 \%)^{*}$ & $113(24.1 \%)^{*}$ & $129(27.6 \%)^{*}$ & $122(26.1 \%)$ & $64(13.70 \%)$ & 468 & 0.004 \\
\hline $\begin{array}{l}\text { Chair side assistant snap impression, polishing of filling } \\
\text { materials, rubber dam etc. }\end{array}$ & $35(7.3 \%) *$ & $107(22.3 \%)^{*}$ & $136(28.4 \%)^{*}$ & $132(27.6 \%)$ & $69(14.40 \%)$ & 479 & $<0.001$ \\
\hline Nursing care & $48(11.0 \%) *$ & $122(27.9 \%)$ & $124(28.3 \%)$ & $94(21.5 \%)$ & 50(11.40\%) & 438 & 0.130 \\
\hline Swallowing function training, & $38(13.6 \%)^{*}$ & $95(34.1 \%)^{*}$ & $69(24.7 \%)$ & $52(18.6 \%)$ & $25(9.00 \%)$ & 279 & $<0.001$ \\
\hline Muscle function training, & $48(13.0 \%)^{*}$ & $112(30.4 \%)^{*}$ & $101(27.4 \%)$ & $76(20.6 \%)$ & $32(8.70 \%)$ & 369 & $<0.001$ \\
\hline Counseling & $40(9.2 \%)$ & $120(27.7 \%)$ & $119(27.5 \%)$ & $100(23.1 \%)$ & $54(12.50 \%)$ & 433 & 0.697 \\
\hline Professional oral care techniques, & $37(12.5 \%)^{*}$ & $85(28.8 \%)$ & $77(26.1 \%)$ & $62(21.0 \%)$ & $34(11.50 \%)$ & 295 & 0.036 \\
\hline Others & $57(9.1 \%)$ & $164(26.2 \%)$ & $182(29.1 \%)$ & $145(23.2 \%)$ & $78(12.50 \%)$ & 626 & 0.783 \\
\hline
\end{tabular}

8 Subjects with No answer for the age groups were excluded from the Table.

*indicated the statistically significant cells by logit model of log-linear analysis.

Table 2. Characteristics of the subjects participated in this study by classification of willingness to reentry.

\begin{tabular}{|c|c|c|c|c|c|c|c|}
\hline & & \multicolumn{4}{|c|}{ Willingness to reentry } & \multirow{2}{*}{\multicolumn{2}{|c|}{ p-value }} \\
\hline & & $\begin{array}{c}\text { As soon as possible } \\
(\mathrm{n}=59)\end{array}$ & $\begin{array}{l}\text { If conditions are satisfied } \\
\qquad(\mathrm{n}=510)\end{array}$ & $\begin{array}{c}\text { I do not intend to } \\
(\mathrm{n}=369)\end{array}$ & $\begin{array}{c}\text { Univalent } \\
(\mathrm{n}=239)\end{array}$ & & \\
\hline Age & $38.2 \pm 11.1^{\S \S, \S \S \S}$ & $41.5 \pm 10.5^{\zeta, \zeta \zeta}$ & $57.4 \pm 10.9^{\zeta \zeta \zeta}$ & $47.8 \pm 11.2$ & $47.6 \pm 12.9$ & $<0.001$ & \\
\hline $\begin{array}{l}\text { Year of } \\
\text { working as } \\
\text { dental } \\
\text { hygienist }\end{array}$ & $11.3 \pm 10.0^{\S \S}$ & $12.6 \pm 8.6^{\zeta}$ & $22.0 \pm 13.2^{\zeta \zeta \zeta}$ & $14.5 \pm 10.4$ & $15.9 \pm 11.4$ & $<0.001$ & \\
\hline $\begin{array}{l}\text { Year since } \\
\text { leaving job }\end{array}$ & $4.2 \pm 7.2^{\S \S, \S \S \S}$ & $5.3 \pm 6.6^{5,5 \zeta}$ & $11.5 \pm 10.3^{5 \zeta 5}$ & $9.2 \pm 9.1$ & $8.0 \pm 8.9$ & $<0.001$ & \\
\hline \multicolumn{8}{|c|}{ The reason of leaving the job. Select one } \\
\hline & Dissatisfaction with work content & $1(5.0 \%)$ & $5(25.0 \%)$ & $7(35.0 \%)$ & $7(35.0 \%)$ & 20 & $<0.001$ \\
\hline & Payment & $0(0 \%)$ & $24(57.1 \%) *$ & $11(26.2 \%)$ & $7(16.7 \%)$ & 42 & \\
\hline & $\begin{array}{l}\text { Trouble in human relations in the } \\
\text { workplace }\end{array}$ & $5(17.9 \%)$ & $12(42.9 \%)$ & $5(17.9 \%)$ & $6(21.4 \%)$ & 28 & \\
\hline & Family Matters & $3(2.4 \%)$ & $60(48.0 \%)$ & $38(30.4 \%)$ & $24(19.2 \%)$ & 125 & \\
\hline & Marriage & $2(4.2 \%)$ & $21(43.8 \%)$ & $12(25.0 \%)$ & $13(27.1 \%)$ & 48 & \\
\hline & Childbirth / child rearing & $23(9.4 \%) *$ & $189(77.5 \%)^{*}$ & $* 7(2.9 \%)$ & $25(10.2 \%)$ & 244 & \\
\hline & $\begin{array}{l}\text { Nursing care for elderlies of your } \\
\text { family }\end{array}$ & $0(0 \%)$ & $18(37.5 \%)$ & $16(33.3 \%)$ & $14(29.2 \%)$ & 48 & \\
\hline
\end{tabular}




\begin{tabular}{|c|c|c|c|c|c|c|}
\hline & \multicolumn{4}{|c|}{ Willingness to reentry } & \multirow[b]{2}{*}{74} & \\
\hline Broke down my health & $1(1.4 \%)$ & $34(45.9 \%)$ & $21(28.4 \%)$ & $18(24.3 \%)$ & & \\
\hline Interests other than dental job & $1(0.8 \%)^{*}$ & $36(27.5 \%)$ & $* 59(45.0 \%)$ & $35(26.7 \%)$ & 131 & \\
\hline Retirement & $5(3.1 \%)$ & $24(14.7 \%)$ & $114(69.9 \%)$ & $20(12.3 \%)$ & 163 & \\
\hline Others & $16(8.0 \%)$ & $61(30.3 \%)$ & $68(33.8 \%)$ & $56(27.9 \%)$ & 201 & \\
\hline \multicolumn{2}{|l|}{ Is there any obstacle for the reentry? } & & & & & \\
\hline Yes & $13(6.5 \%)$ & $62(31.0 \%)^{*}$ & $80(40.0 \%)^{*}$ & $45(22.5 \%)$ & 200 & $<0.001$ \\
\hline \multicolumn{2}{|l|}{ What is your obstacle for reentry? } & & & & & \\
\hline Salary & $4(2.1 \%)^{*}$ & $115(59.6 \%)$ & $33(17.1 \%)$ & $41(21.2 \%)$ & 193 & 0.002 \\
\hline Working hours & $28(5.7 \%)^{*}$ & $319(65.1 \%) *$ & $55(11.2 \%)^{*}$ & $88(18.0 \%)$ & 490 & $<0.001$ \\
\hline My skills & $17(3.8 \%)^{*}$ & $208(46.0 \%)^{*}$ & $110(24.3 \%)^{*}$ & $117(25.9 \%)$ & 452 & 0.004 \\
\hline No consultation & $1(3.0 \%)$ & $23(69.7 \%)$ & $1(3.0 \%)^{*}$ & $8(24.2 \%)$ & 33 & 0.023 \\
\hline Aging & $7(2.4 \%)$ & $91(30.7 \%)$ & $121(40.9 \%)$ & $77(26.0 \%)^{*}$ & 296 & $<0.001$ \\
\hline Others & $16(9.8 \%)$ & $76(46.3 \%)$ & $38(23.2 \%)$ & $34(20.7 \%)$ & 164 & 0.023 \\
\hline
\end{tabular}

21 Subjects with No answer for Willingness to reentry were excluded from the Table.

Statistically significant difference between

$\S$ : As soon as possible and If conditions are satisfied, $\S \S$ : As soon as possible and I do not intend to

$\S \S \S$ : As soon as possible and Univalent, $\zeta$ : If conditions are satisfied and I do not intend to, $\zeta \zeta$ : If conditions are satisfied and Univalent, $\zeta \zeta \zeta$ : I do not intend to and Univalent, respectively.

- Statistically significant cell by log-linear analysis

Characteristics of the subject classified by willingness to reenter were shown in Table $\mathbf{2}$. The subjects with willingness to reenter (As soon as possible and If conditions are satisfied) were younger than subjects without willingness to reentry (I do not intend to and Univalent). Therefore, the subjects who wished reentry had shorter years of working experience as a dental hygienist and shorter year since leaving the jobs.

Childbirth / child rearing were statistically significant reason for leaving the job for the subjects with willingness to reentry. Payment were significant only for the subjects who answered if conditions are satisfied, however, the number of the subjects who selected if conditions are satisfied were high. In the subjects not intending to reenter, interests other than dental job were significant. Working hours and skills were significant obstacles for reentry.
Fig. (1) shows the results of decision analysis, if obstacle of reentry was working hours, the reason for job leaving was childbirth / child rearing and year since leaving job was less than 10 year, $94.9 \%$ subjects had willingness to reenter. If obstacle of reentry was not working hours and year of working as dental hygienist was more than 26 years, $75.4 \%$ subjects had no willingness to reenter. Even though obstacle of reentry was not working hours and year of working as dental hygienist was more than 26 years, if the reason of leaving job was family matters, nursing care for elderlies of your family, health issues, or retirement, $55.0 \%$ subjects had no willingness to reenter. If obstacle of reentry was not working hours and year of working as dental hygienist was less than 25 years, and year since leaving job was less than 2 year, $64.2 \%$ subjects had willingness to reenter.

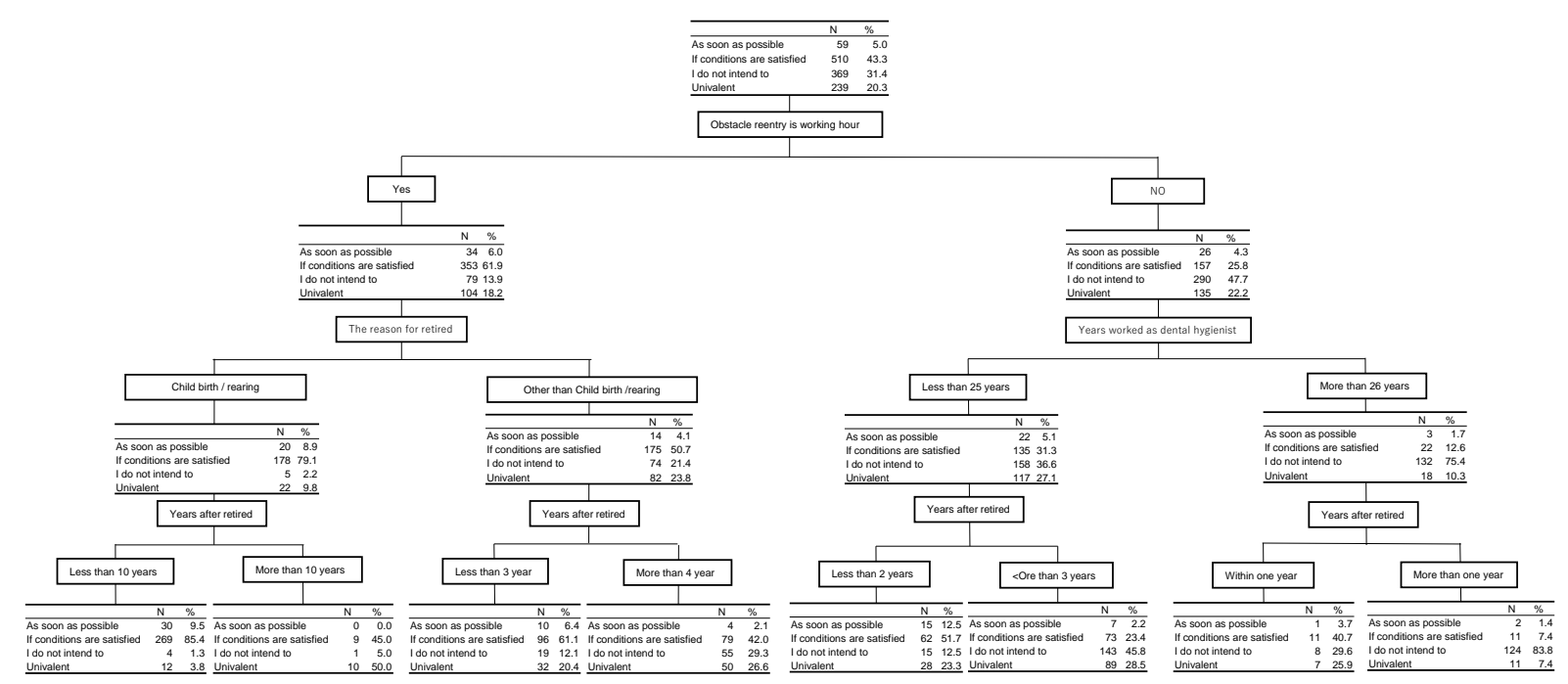

Fig. (1). Decision analysis for the willing ness of reentry of the dental hygienist jobs

Working hours was the most important determinant of the willingness of reentry. Among the 59 dental hygienist who willing to reentry for the jobs as soon as possible, 30 subjects had following conditions: obstacle for reentry was working hours, the reason of retired as child birth/ rearing, and less than 2 years after retired. 


\section{DISCUSSION}

The scope of work of dental hygienists differs between countries. Visiting oral care by the elderlies or medically handy capped patients for dental hygienist without dentist are approved by the Japanese insurance system. The ratio of dental hygienists to general dentists in Japan was 1:1. The value of it was similar in United States, Canada, Australia, and Germany [14 - 17]. It was higher than that of Australia, Germany, Italy and Israel [14, 16 - 18]. However, in accordance with the elderly population in Japan, workforce of dental hygienist is indispensable. Other than that, dental hygienists are a major dental human resource in all countries [19].

Most of the Japanese dental hygienists were employed in private dental offices [2]. This situation differs between countries. For example, $47.0 \%$ for United Kingdom [20] and $40.0 \%$ for Hong Kong [21], and 91.5\% for Australia [15]. This should be noted, when comparing the results of this study with the other countries.

In Japan, for the education of undergraduate dental hygienist, eight universities provide bachelor's degree program and all of the vocational dental hygienist schools are providing a 3-year diploma program since 2010 . The dental hygiene curriculum included oral care and the evaluation of chewing and swallowing function for medically dependent patients [12]. However, post graduate and life-long skills are necessary. Due to this, Japan Dental Hygienist Association provides advanced skill up seminars and diploma course on an every prefectures branch basis. The contents of seminars are swallowing function training, muscle function training, paramedic etc. However, the dental hygienist who had left their job needed more basic training course (Table 1). Additional planning of the lecture course is necessary for the Japanese Dental Hygienist Association for reentry.

Childbirth / rearing and working hours had the most important impact on leaving job and obstacle for reentry. In this study, the number of dental hygienist who left the job due to childbirth / rearing was highest. Highest obstacle for the reentry was working hours. In addition, dental highest who had the willingness of reentry leave the job and their obstacle for the reentry was working hours. It may be a general trend worldwide $[15,20,22]$. In addition, hygienists with childcare responsibilities were likely to be part time workers [20, 22]. For the working hours, it was reported that dental hygienists were generally satisfied with flexibility in working hours [23, 24]. However, working styles of dental hygienist varied between the countries. In Japan, as described in introduction, most of the dental hygienist employed by the private dental clinic, and the ratio of dental hygienist/dentist was 1:1. Many private dental offices in Japan open until late at night like eight or $9 \mathrm{pm}$. In addition, some of the private dental offices open on holidays, many of the private dental offices have shifts for the staff. Under these conditions, many of the dental Japanese hygienist may not be satisfied with the working hours and it can be the most important obstacle in reentry. To overcome these conditions, social support system is indispensable. Japanese government has tried to improve women's working environment, however, the measures taken are not enough.

Some of the young dental hygienist leave their job due to trouble in human relations at the workplace or dissatisfaction with work content. Japanese students are enrolled in the dental hygiene program immediately after high-school graduation without any work experiences. A large part of education for dental hygienist students was carried out by 3 -year diploma program at the vocational dental hygienist schools. Motivation', 'Expectation' and 'Environment' were significantly higher among the Canadian students over Japanese students [25, 26]. Several reports had shown that dental hygienists could obtain higher levels of career satisfaction [20, 27 - 29]. Job satisfaction of older dental hygienists was higher than that of younger dental hygienists [20,29]. However, for the young Japanese dental hygienist, the length of education and practical experience may not be enough to obtain career satisfaction and job satisfaction. Previous study concluded that continuing professional development is a lower priority than workplace improvement for the dental hygienist [30].Therefore, workplace improvement including flexible working time may be most important factors for the reentry of the dental hygienist who have left their jobs.

One of the limitations of this study was this sampling frame. The study population was limited to the members of the Japan Dental Hygienists Association. However, fundamentally, these obstacles were derived from the regulation by the Japanese national insurance system and most of the work place is small scale private dental office. Japanese national insurance system regulates payment of dental service fees. Fees are regulated at piecework payment basis. The fee for dental hygienist is not enough. Most of the Japanese dentist are sole proprietors. The welfare of small company is not enough. The style of Japanese dental service system may have reached the limit. Intervention by government may be indispensable to improve the dental service supply system including dental hygienist employment system.

\section{CONCLUSION}

Workplace improvement including flexible working time may be the most important factors for the reentry of the dental hygienist who have left their jobs. Social support system is indispensable to improve women's working environment.

\section{ABBREVIATION}

\section{CART $=$ Classification and Regression Trees}

\section{ETHICS APPROVAL AND CONSENT TO PARTICIPATE}

This study was approved by the Ethics Committee of Tsurumi University School of Dental Medicine, Japan (approval number:1633).

\section{HUMAN AND ANIMAL RIGHTS}

No animals were used in this research. The reported analysis was in accordance with the ethical standards of the committee responsible for human experimentation (institutionaland national) and the Helsinki Declaration of 1975, as revised in 2013 .

\section{CONSENT FOR PUBLICATION}

Written informed consent was obtained from all participants when questionnaire was returned. 


\section{AVAILABILITY OF DATA AND MATERIALS}

All data that support the results of this study are with Japan Dental Hygienist Association and can be made available upon reasonable request.

\section{CONFLICT OF INTEREST}

The authors declare no conflict of interest, financial or otherwise.

\section{ACKNOWLEDGEMENTS}

Declared none.

\section{SUPPLEMENTARY MATERIAL}

Supplementary material is available on the publishers website along with the published article.

\section{REFERENCES}

[1] Japanese population, Statistic Bureau, Ministry of Internal Affairs and Communications Japan http://www.stat.go.jp/index.html(2019, November, 1 , accessed)

[2] Report on Public Health Administration and Services, Overview of employment medical personnel Ministry of Health, Labor and Welfare Japan

https://www.mhlw.go.jp/toukei/saikin/hw/eisei/16/dl/gaikyo.pdf2020.

[3] Vital Statistics Ministry of Health, Labor and Welfare Japan www.mhlw.go.jp/toukei/saikin/hw/jinkou/geppo/nengai17/dl/kekka.pd $\mathrm{f}(2020$, January, 15 , accessed)

[4] Barnes CM. Dental hygiene intervention to prevent nosocomial pneumonias. J Evid Based Dent Pract 2014; 14(Suppl.): 103-14. [http://dx.doi.org/10.1016/j.jebdp.2014.02.002] [PMID: 24929595]

[5] Yoon MN, Steele CM. Health care professionals' perspectives on oral care for long-term care residents: nursing staff, speech-language pathologists and dental hygienists. Gerodontology 2012; 29(2): e525-35.

[http://dx.doi.org/10.1111/j.1741-2358.2011.00513.x] [PMID: 22462684]

[6] Adachi M, Ishihara K, Abe S, Okuda K. Professional oral health care by dental hygienists reduced respiratory infections in elderly persons requiring nursing care. Int J Dent Hyg 2007; 5(2): 69-74.

[http://dx.doi.org/10.1111/j.1601-5037.2007.00233.x] [PMID: 17461957]

[7] Adachi M, Ishihara K, Abe S, Okuda K, Ishikawa T. Effect of professional oral health care on the elderly living in nursing homes. Oral Surg Oral Med Oral Pathol Oral Radiol Endod 2002; 94(2): 191-5.

[http://dx.doi.org/10.1067/moe.2002.123493] [PMID: 12221387]

[8] Abe S, Ishihara K, Adachi M, Sasaki H, Tanaka K, Okuda K. Professional oral care reduces influenza infection in elderly. Arch Gerontol Geriatr 2006; 43(2): 157-64.

[http://dx.doi.org/10.1016/j.archger.2005.10.004] [PMID: 16325937]

[9] Survey of Medical Institutions Ministry of Health, Labor and Welfare Japan www.mhlw.go.jp/toukei/saikin/hw/iryosd/16/d1/02_01.pdf(2019, November,11, accessed)

[10] Yoshida T, Eda S, Takaku S. Study on employee as dental hygienists in dental institutions: SaitamaPref. Japanese J Dent Prac Adm 2010; 44: 216-26. [in Japanese].

[11] Ueda Y, Yagun A, Nagasaki Y, Kago M, Katayama S. Study on the reinstatement of unemployed dental hygienists: Kanagawa Pref. (in Japanese) Japanese. J Dent Pract Adm 2011; 45: 286-93.

[12] Usui Y, Miura H. Workforce re-entry for Japanese unemployed dental hygienists. Int J Dent Hyg 2015; 13(1): 74-8. [http://dx.doi.org/10.1111/idh.12101] [PMID: 25163393]

[13] Survey of working environment of Japanese dental hygienist www.jdha.or.jp/aboutdh/chosa.html\#datakinmu2020.

14] Abadi N, Mann J, Sela M, Zusman SP. Professional relationship between dentists and dental hygienists in Israel Isr Dent Hyg Assoc J 2008; 31: 8-12.

[15] Hopcraft M, McNally C, Ng C, et al. Working practices and job satisfaction of Victorian dental hygienists. Aust Dent J 2008; 53(1): 61-6.

[http://dx.doi.org/10.1111/j.1834-7819.2007.00011.x]

[PMID: 18304243

[16] Johnson PM. International profiles of dental hygiene 1987 to 2006: a 21-nation comparative study. Int Dent J 2009; 59(2): 63-77. [PMID: 19489285]

[17] Johnson PM. International profiles of dental hygiene 1987 to 2006: a 21-nation comparative study. Int Dent J 2009; 59(2): 63-77. [PMID: 19489285]

[18] Braunstein N, Mann J, Sela M. Professional relationship between dentists and hygienists in Israel. Adkan 2009; 103: 15-20.

[19] Yavnai N, Bilder L, Sgan-Cohen H, Zini A. Dental hygienists in Israel: employment evaluation, job satisfaction, and training implications. J Dent Educ 2012; 76(10): 1371-6.

[PMID: 23066137]

[20] Gibbons DE, Corrigan M, Newton JT. A national survey of dental hygienists: working patterns and job satisfaction. Br Dent J 2001; 190(4): 207-10

[http://dx.doi.org/10.1038/sj.bdj.4800926] [PMID: 11270388]

[21] Fung DS, Schwarz E, Tong AC, Wong MC. Dental hygienists in Hong Kong: present and future status. J Dent Hyg 1996; 70(2): 66-73. [PMID: 9161216]

[22] Ayers K, Meldrum AM, Thomson WM, Newton JT. The working practices and job satisfaction of dental hygienists in New Zealand. J Public Health Dent 2006; 66(3): 186-91.

[http://dx.doi.org/10.1111/j.1752-7325.2006.tb02578.x] [PMID: 16913245

[23] Malkawi ZA. Career satisfaction of Jordanian dental hygienists. Int J Dent Hyg 2016; 14(4): 243-8.

[http://dx.doi.org/10.1111/idh.12168] [PMID: 26234547]

[24] Calley KH, Hodges KO, Johnson R. Prioritization of professional issues by Idaho Dental Hygienists. J Dent Hyg 2001; 75(3): 222-31. [PMID: 11603304]

[25] Saito A, Tomita C, Sato Y, Cathcart G. Perceptions of Japanese and Canadian dental hygiene students towards their profession. Int J Dent Hyg 2009; 7(3): 188-95.

[http://dx.doi.org/10.1111/j.1601-5037.2009.00388.x]

[PMID: 19659715

[26] Saito A, Sato Y, Nakamura A, et al. Development of an International Collaborative Dental Hygiene Programme between Japan and Canada. Int J Dent Hyg 2008; 6(4): 328-36.

[http://dx.doi.org/10.1111/j.1601-5037.2008.00309.x] [PMID: 19138184]

[27] Hillam DG. A survey of hygienists qualifying from the Liverpool School of Dental Hygiene 1977-1998. Br Dent J 2000; 188(3): 150-3. [http://dx.doi.org/10.1038/sj.bdj.4800417] [PMID: 10718002]

[28] Boyer EM. Job satisfaction among dental hygienists. J Dent Hyg 1990; 64(5): 235-8. [PMID: 2074490]

[29] Schou L, Tronbjerg C, Holst I. A national survey of dental hygienists in Denmark. Community Dent Health 1986; 3(1): 91-8. [PMID: 3457619]

[30] Petrén V, Levin G, Chohan T, Preber H, Candell A, Bergström J. Swedish dental hygienists' preferences for workplace improvement and continuing professional development. Int J Dent Hyg 2005; 3(3): 117-25.

[http://dx.doi.org/10.1111/j.1601-5037.2005.00138.x] [PMID: 16451362]

This is an open access article distributed under the terms of the Creative Commons Attribution 4.0 International Public License (CC-BY 4.0), a copy of which is available at: https://creativecommons.org/licenses/by/4.0/legalcode. This license permits unrestricted use, distribution, and reproduction in any medium, provided the original author and source are credited. 